Radosław Sławomirski

\title{
Władimir Wysocki - pomiędzy kulturą wysoką a popularną
}

Wraz z dziewiętnastowieczną rewolucją przemysłową i przypadającym na drugą połowę 20. stulecia rozwojem społeczeństwa informacyjnego, kulturę w dotychczasowym rozumieniu, czyli sferę zarezerwowaną raczej dla elit zaczyna wypierać kultura masowa (popkultura). Łączy się to z rozwojem mediów: prasy, telewizji i radia, które umożliwiły prostemu robotnikowi, czy chłopu obcowanie z kultura przy stosunkowo niewielkich nakładach finansowych. Jednak szeroki rozkwit kultury popularnej przypada na XX wiek, który charakteryzuje powstanie globalnej, błyskawicznie rozwijającej się sieci Internet i trwa do czasów współczesnych, w których specyficzny język reklamy, ale także pojęcia zaczerpnięte $\mathrm{z}$ Internetu, wchodzą w codzienny obieg, jak np. wyrażenie nie spamuj mi, które pierwotnie odnosiło się do niechcianej, wysyłanej w celach reklamowych poczty elektronicznej (spam), a w użyciu potocznym oznacza już sprzeciw na przekazywanie zbędnych informacji. Można powiedzieć, że rozwój mediów wyciągnął kulturę - a zwłaszcza takie jej gatunki, jak teatr, opera czy elitarne koncerty - z niszy, w jakiej się do tej pory znajdowała, dla szerokich kręgów społecznych, a co za tym idzie otworzył jej drzwi do niższych, niż dotychczas warstw społecznych. To, oczywiście wymusiło pewne znaczące zmiany w dotychczasowym rozumieniu kultury, którą zresztą słusznie nazwano, w odróżnieniu od tradycyjnej „kultury wysokiej”, kultura popularna. Zmiany te prowadziły nieuchronnie do znacznych przemian, co do formy i treści wytworów kultury.

Powstanie masowej kultury nie zakończyło rozwoju kultury wysokiej. Doprowadziło to jednak do dwutorowości w rozwoju kultury. Kultura wysoka pozostała, wciąż dostępną tylko elitarnemu odbiorcy. 
Na dwutorowość kultury zachodniej, czyli dotyczącej krajów rozwiniętych, już w 1953 roku zwrócił uwagę Dwight Macdonald, pisząc:

Od około stu lat kultura zachodnia tak naprawdę składa się z dwóch kultur: tradycyjnej (nazwijmy ją 'Kulturą Wysoką'), odnotowywanej w podręcznikach, oraz 'Kultury Masowej', produkowanej w ilościach hurtowych, by zaspokoić rynek. (...) Kultura Masowa rozwinęła także własne środki przekazu, którymi rzadko posługują się poważni artyści: radio, filmy, komiksy, kryminały, science-fiction, telewizja. Czasem bywa nazywana 'Kulturą Popularną', jednak sądzę, że termin 'Kultura Masowa' jest bardziej adekwatny, ponieważ jej główną cechą jest to, że jest produktem tworzonym wyłącznie i bezpośrednio na potrzeby masowej konsumpcji, jak guma do żucia [Macdonald 1953: 1].

Oczywiście istnieją próby łączenia kultury masowej z tradycyjnymi formami kultury, jak np. przenoszenie inscenizacji teatralnych na ekran telewizyjny, jednak nie jest to, tematem niniejszego artykułu, tak jak i to, że coraz więcej elementów popkultury, włącznie z językiem, przenika do współczesnej „kultury wysokiej”, co łatwo wykazać na przykładzie współczesnych tekstów poetyckich. Powiązane jest to zresztą z rewolucją kulturową lat 60 . XX wieku, zmianą obrazu literatury, a tym samym zmianą kultury wysokiej [zob. także: Martuszewska 1997].

Kulturę popularną, nazywaną w skrócie popkultura, w odróżnieniu od tzw. „kultury wysokiej”, określanej także mianem „kultury elitarnej”, cechuje znacznie szerszy krąg odbiorców, stąd nie bezpodstawne jest przywołanie odbiorcy masowego - w odniesieniu do popkultury i odbiorcy elitarnego - w odniesieniu do kultury wysokiej, którego często - co widzimy chociażby na przykładzie poczytności współczesnej poezji - możemy utożsamiać wręcz z odbiorcą niszowym.

Wartym zauważenia wydaje się być aspekt historyczny powstania popkultury. Gdy w dwudziestym wieku kultura masowa w krajach „wolnych” rozwijała się sterowana zapotrzebowaniem demokratycznej większości oraz, a może należałoby powiedzieć - przede wszystkim - komercyjnymi prawami rynku, to ciekawy zabieg miał miejsce w państwach totalitarnych, takich jak ZSRR, gdzie władza zdała sobie 
sprawę, że kulturę, a szczególnie literaturę, ale także jej nowe formy, takie jak film, można wykorzystać do celów ideologicznych indoktrynując społeczeństwo. Przy wsparciu finansowym Związku Sowieckiego powstał szereg propagandowych filmów ukazujących szczęście płynące z budowy socjalizmu, szlachetności żołnierzy walczących z nazistowskim najeźdźcom w imię lepszej - oczywiście socjalistycznej - przyszłości, czy produkcje wychwalające przywódców Imperium Zła, jak określa się Związek Sowiecki, z postacią Lenina na pierwszym planie. Podobne zabiegi miały miejsce w malarstwie, rzeźbie, czy w literaturze. Co do wagi, jaką przywiązywała władza tej ostatniej, świadczy między innymi fakt powołania specjalnej instytucji cenzora, który sprawdzając poprawność polityczną danego dzieła decydował o ewentualnym dopuszczeniu jego do druku, bądź skazaniu na niebyt, a nawet internowania niepokornych autorów. Tych ostatnich zwykle zamykano w zakładach psychiatrycznych, które w tamtych czasach stawały się więzieniami dla dysydentów. Literacką aluzję do tego procesu znajdujemy w powieści Mistrz i Małgorzata (Macmep u Mapzapuma) Michaiła Bułhakowa, gdzie główny bohater, poeta Iwan „Bezdomny”, wbrew własnej woli, zostaje uznany za niepoczytalnego i zamknięty w szpitalu psychiatrycznym.

Uwięzienie poety, który zna niewygodną prawdę, „kneblowanie ust" poetą nie było tylko fikcją literacką, bowiem to właśnie w poezji władza upatrzyła sobie instrument walki propagandowej, co oczywiście musiało odbić się negatywnie na tym gatunku literackim. Jak pisze Florian Nieuważny w Historii literatury rosyjskiej XX wieku, pod redakcją Andrzeja Drawicza:

Nadmiernie wąskie, dogmatyczne traktowanie poezji, ograniczenie jej do funkcji agitacyjnych i ilustratywnych, pozbawienie liryki prawa do ujawnienia konfliktów duchowych, do zgłębienia skomplikowanych aspektów życia człowieka i społeczeństwa, do stawiania pytań, na które poeci nie zawsze mogli znaleźć odpowiedzi - wszystko to powodowało odsunięcie się poezji na dalszy plan w procesie literackim. (...) prowadziło bezsprzecznie do unifikacji stylu i szarzyzny w poezji [Nieuważny 2007: 462-473]. 
Florian Nieuważny zwraca też uwagę, że po silnych zmianach spowodowanych stalinizmem chruszczowowska odwilż przyniosła chwilowe odprężenie w poezji:

(...) od połowy lat 50. sytuacja wyraźnie ulega zmianie. (...) Połowę lat 50. charakteryzuje wzrost aktywności poetów starszego pokolenia i poszerzenie sposobów widzenia świata o nowe formy poetyckiej wypowiedzi: od folklorystycznej stylizacji (Prokofjew) przez zakotwiczony w codzienności romantyzm (Swietłow) ku medytacjom nad zagadką więzi łączącej człowieka z przyrodą i historią, nad złożonością relacji między prawdą i dobrem [Nieuważny 2007: 462-473].

Nie bez znaczenia wydają się być przytoczone słowa Nieuważnego w przypadku omawiania twórczości poetyckiej Władimira Wysockiego, którego debiut przypada właśnie na czas „odwilży”. Twórczość ta na powyższym, skażonym totalitaryzmem, socrealistycznym tle jest ciekawym fenomenem. Fenomenem nazywają ją również Przemysław Słowiński i Iwona Wygoda we wstępie do powieści biograficznej, poświęconej temu rosyjskiemu artyście Nie uśmiecha się życie do wilków, pisząc: „Twórczość Wysockiego stała się fenomenem zarówno kulturowym, jak też społecznym i politycznym, jako głos upodlonego przez zbrodniczy system narodu" [Słowiński, Wygoda 2008: 11].

Niewątpliwie przekracza ona granice pomiędzy „kulturą wysoką”, jaką bez wątpienia jest tradycyjna poezja, a kulturą popularną, która charakteryzuje muzykę rozrywkową. O tym, że ballady Władimira Wysockiego są poezją świadczą chociażby słowa rosyjskiego noblisty, literata - Josifa Brodskiego, który nazwał Wysockiego „największym poetą Rosji", zaś o tym, że Władimir Wysocki stał się symbolem rosyjskiej kultury masowej, świadczą rzesze fanów, jakie otaczały go na koncertach, które najczęściej odbywały się bez żadnej zapowiedzi, a ludzie dowiadywali się o nich przekazując sobie tą informacje, czy tłumy na przedstawieniach teatralnych $\mathrm{z}$ jego udziałem.

Warto postawić sobie pytanie czy twórczość Władimira Wysockiego nosiła elementy popkultury? Pozytywnie na to pytanie pozwala odpowiedzieć sam język, a więc niezbędny element poezji Władimira 
Wysockiego. Cechuje go ogrom kolokwializmów, potoczności, z rzadka pojawiają się też wulgaryzmy. Dobry przykład języka, jakim w swoich balladach posługiwał się Woładia, jak często określają - używając tylko zdrobniałej formy imienia - tego barda Rosjanie, odnajdujemy w wierszu pt. Аиалог у телевизора:

- Ой, Вань, смотри, какие кмоуны:

рот - хочь завязочки пришей!

Ой, Ао чего, Вань, размалёваны, а голос - как у алкашей!

А тот похож - нет, правда, Вань, на шурина - такая ж пьянь.

Ну нет, ты глянь, нет- нет, ты глянь, я вправду, Вань!

- Поскушай, Зин: не трогай шурина, какой ни есть, а он родня!

Сама намазана, прокурена, гАяАИ, АОЖАешься У меня!

А чем болтать, взяла бы, Зин, в антракт сгоняла $б$ в магазин... Что, не пойАешь? Ну, я оАин. Подвинься, Зин! (..)

...Ого, однако же, - гимнасточка! ГАяАИ- ка: ноги на винтах.

У нас в кафе молочном « $\Lambda$ асточка» официантка может так...

А у тебя подруги, Зин, всё вяжут шапочки Аля зим, от ихних скучных образин Ауреешь, Зин! 
- Как, Вань, а Аимька Федосеева, кассирша из ЦПКиО?

Ты к ней всё мез на новоселии;

она - так очень ничего!

А чем ругаться, кучше, Вань, поедем в отпуск в Еревань...

Ну что «отстань », опять «отстань»...

Обилно, Вань!

[Wysocki 1986: 45-46]

Tłumaczenie Bogusława Wróblewskiego oddaje specyfikę języka - przesyconego kolokwializmami, czy słowami dalekimi od języka literackiego, takimi jak: „błazny”, „ochlaptus”, „bełt” czy w końcu zwrotami o zabarwieniu wulgarnym: „nie piernicz, nie rusz, masz mordę” - w powyższej balladzie. Polska wersja tej ballady nosi tytuł: Rozmowa przed telewizorem i brzmi następująco:

- Oj, popatrz Wańka, jakie błazny,

Toż bez wyroku po pięć lat,

A mordy im się tak rozlazły,

Że mogą opluć cały świat,

A tamten całkiem jak twój wuj,

Ale ochlaptus, Boże mój,

No nie, no stój, nie ruszaj, stój,

Patrz, żywcem wuj.

- Nie piernicz, Zino, nie rusz wuja, Jaki by nie był, ale nasz, Sama masz mordę jak szczeżuja, A jeszcze mi na nerwach grasz...

A zamiast gadać byle co

Po flaszkę skocz, bo wyschło szkło.

Nie pójdziesz? Dobrze, zniosę to.

Posuń się no! 
(...)

- Oj, popatrz, Wańka, akrobata!

Skubany, kręci się jak bąk!

Nasz majster też tak w klubie latał,

A stołka nie wypuścił z rąk!

Ty Wańka, znowu śpisz lub jesz,

Jak trzeźwy jesteś, to się ciesz!

Mam dosyć twoich fochów, wiesz?

I ciebie też!

- Jak mnie bez przerwy denerwujesz,

To nie dziw się, że jestem zły,

Człowiek się w pracy naharuje,

Wraca do domu, a tam ty.

Każdy ma chyba prawo żyć,

Więc zamiast tu co wieczór tkwić,

Wolę z kumplami częściej być,

Nie chcę sam pić

[Wysocki 1986: 43-45].

Przez to język bohaterów literackich Wysockiego, był językiem zwykłych ludzi, którzy dzięki temu zabiegowi poetyckiemu mogli utożsamiać się z bohaterami pieśni i samym bardem, który podczas swoich wystąpień scenicznych potrafil tak wczuć się w sytuacje, o których śpiewał, jakby za każdym razem śpiewał o samym sobie:

Autentyczność jego uzdolnień była tak duża, że wielu ludzi było przekonanych, iż wszystko to on sam przeżył. Lepili biografię artysty z jego pieśni: walczył na froncie, żeglował, był alpinistą, pracował jako szofer, szukał złota, omal nie zatonął $w$ łodzi podwodnej i siedział w więzieniu [Słowiński, Wygoda 2008: 11]

Jak puentują autorzy tych wspomnień:

„Wysocki nie tylko pisał i śpiewał, nie tylko współczuł, on cierpiał i umierał razem ze swymi bohaterami” [Tamże]. 
Ta autentyczność właśnie oraz to, że Wysocki śpiewał o zwyczajnych ludziach, językiem zwyczajnych ludzi - swoich literackich bohaterów, o ich pragnieniach, czy dążeniach sprawiało, że ballady te, tak łatwo zapadały w pamięć współczesnych poecie, były przez nich cytowane, czy wręcz odtwarzane. Przyśpiewane przy akompaniamencie gitary stawały się nierozłącznym elementem wielu spotkań, przyjęć towarzyskich.

Olbrzymia popularność, jaką cieszył się Wysocki wśród jemu współczesnych oraz zastosowane przez niego środki literackie upoważniają nas do stwierdzenia, że piosenki poetyckie Wysockiego zawierają elementy charakterystyczne dla kultury popularnej. Jednak już przy pobieżnej analizie poetyckich pieśni Wysockiego można wykazać, że twórczość rosyjskiego barda przynależy do kultury wysokiej.

\section{Bibliografia}

Buthakow M. [1967], Macmep u Mapzapuma, YMCA-PRESS, Paryż.

Macdonald D. [1953], A Theory of Mass Culture, „Diogenes”, nr 1(3), s. 1-17. Martuszewska A. [1997], „Ta trzecia”. Problemy literatury popularnej, Wydawnictwo Uniwersytetu Gdańskiego, Gdańsk.

Nieuważny F. [2007], Poezja, [w:] Historia literatury rosyjskiej XX wieku. Część III - literatura po roku 1953, Drawicz A. (red.), PWN, Warszawa.

Słowiński P., Wygoda I. [2008], Nie uśmiecha się życie do wilków... Ballada o Włodzimierzu Wysockim, Videograf II, Chorzów.

Wysocki W. [1986], Pieśni i wierze, Czytelnik, Lublin.

Wysocki W. [1995], Kapryśne konie. Wiersze i pieśni w przekładzie Marleny Zimnej, Pracownia Introligatorsko-Poligraficzna „Intro-Druk”, Koszalin. 